Original Research

\title{
Middle School Students' Perception on a Health Promoting School to Prevent Bullying: A Qualitative Study
}

\section{Masunatul Ubudiyah, Nursalam Nursalam and Tintin Sukartini}

Faculty of Nursing, Universitas Airlangga, Surabaya, East Java, Indonesia

\begin{abstract}
Introduction: Bullying at school is an old phenomenon in the adolescent group. Despite massive prevention programs, it has not yet resolved by teachers and schools, and this also can affect school climate aspects. The aim of this study was to explore students' perceptions who are being bullying victims about health promoting schools to prevent bullying at school.
\end{abstract}

Methods: This study used a qualitative case study design. The research sample was 18 middle school students in grades 8 and 9 in East and West Surabaya. A sample was recruited through snowball sampling. Interview guidelines were used to collect the data through in-depth interviews. The data were subjected to thematic analysis.

Results: Middle school students identified three main requirements related to prevent bullying were health education, health services, and healthy school environment. These themes were found among the participants with a bullying victim's history.

Conclusion: Health education, health services, and healthy school environment are the theme for preventing bullying cases at school. To prevent bullying requires collaboration from various parties, such as students, teachers and school policy makers to be able to apply the rules while in school.

\section{ARTICLE HISTORY}

Received: November 25, 2020

Accepted: January 11, 2021

\section{KEYWORDS}

bullying; health promoting school; adolescent

\section{CONTACT}

Tintin Sukartini

$凶$ tintin-s@fkp.unair.ac.id

$\doteq$ Faculty of Nursing,

Universitas Airlangga,

Surabaya, East Java, Indonesia

Cite this as: Ubudiyah, M., Nursalam, N., \& Sukartini, T. (2021). Middle School Students' Perception on a Health Promoting School to Prevent Bullying: A Qualitative Study. Jurnal Ners, 16(1). 6-12. doi:http://dx.doi.org/10.20473/in.v16i1.23399

\section{INTRODUCTION}

The role of a health promoting school is still massive and has not yet resolved bullying cases in Indonesia, so that the involvement of the school's role is very important. Bullying at school is still a phenomenon or problem in adolescent groups around the world, although the prevalence varies between countries (Bowes et al., 2019; Låftman, Östberg, \& Modin, 2017). Bullying is a form of aggressive behavior designed to hurt other people, which occurs repeatedly or more than once and also causes an imbalance in power so that the victim finds it difficult to protect or defend themselves (Smith, 2016). Various types of bullying that occur in the adolescent group include physical, verbal, social, psychological, and cyberbullying (UNICEF, 2018). There are different types of bullying, namely, indirect or relational bullying (Olweus, Limber, \& Breivik, 2019). Bullying has both short-term and long-term effects on students. Bullying on adolescents students found in schools can affect social interactions, such as students feel insecure or unsafe (Jan, 2015). Furthermore, bullying has an impact on decreasing academic performance for victims of bullying at school (Barrington, 2018). Based on these problems, schools and school health organizations need to be involved in efforts to prevent bullying in schools.

In Southeast Asian countries, Indonesians reported higher rates of student bullying than in the Philippines at $20.6 \%$ and $13.1 \%$, respectively (Sittichai \& Smith, 2015). In 2015, the Indonesian Ministry of Social Affairs reported that $40 \%$ of Indonesian students or children experienced cases of planning suicide as a result of bullying that occurred in the 10-14 year age group (Khidhir, 2019; Ruangnapakul, Salam, \& Shawkat, 2019). According to East Java Child Protection Agency data, there were 567 children involved as perpetrators and 408 children who were direct victims in 2019, with the highest prevalence in Surabaya and Tulung Agung (Puspita, 2019). 
Bullying is the aggressive activity by someone to hurt, to offend or also to push another person, done repeatedly, and aims to show the strength of the perpetrator to the victim (Pontes, Pontes, Ayres, \& Lewandowski, 2018). Bullying at school is defined as aggressive behavior that occurs in a school environment that arises in students who are influenced by the power to bully their friends (Shayo \& Lawala, 2019). The negative impact of bullying can affect several aspects, including physical and mental health (Murshid, 2017). Bullying can occur to the perpetrator, the victim and the surrounding environment; this will affect their autonomy so that a person will feel dissatisfied with their life, making social relationships unharmonious and decrease the ability to complete tasks (Meriläinen, Kõiv, \& Honkanen, 2019).

Previous research describes bullying prevention programs in schools by involving police officers (Devlin, Santos, \& Gottfredson, 2018); involving all of the school's components (Acosta et al., 2019); and teaching life skills to students (Fekkes, 2016). In addition, many studies have revealed teachers' perceptions about reporting cases of bullying (Blust, 2016), teachers' perceptions of bullying (Ali, Mobarki, Mohamed, Morsi, \& Hamouda, 2020; Hayes, 2017). However, there has been no research on students' perceptions of bullying and health promoting schools as one of the preventions of bullying in schools. Indonesian Health Promoting School, often referred to as UKS is an abbreviation of "Usaha Kesehatan Sekolah" in Bahasa. The Minister of Education and Culture said that UKS had been used as the spearhead of health services in schools centered on health education, health services and the development of a healthy school environment (Kementerian Pendidikan dan Kebudayaan, 2012). Accordingly, this study is expected to be able to provide an overview of solutions to prevent bullying in schools through health promoting school activities based on the experiences of victims of bullying at school.

\section{MATERIALS AND METHODS}

This qualitative inquiry used a case study approach in order to have in-depth information about the informants. Participants were taken in Surabaya, the second metropolitan city in Indonesia with a fairly high youth coverage, in particular eastern and western Surabaya. Consolidated criteria for reporting qualitative studies (COREQ), a 32-item checklist, was used by researchers to assess and report the results (Tong, Sainsbury, \& Craig, 2007). The inclusion criteria specified are bullying victims aged 13-15 who are currently undergoing their middle school studies. Participants have at least involved being victims of bullying in the past one month, either verbal, physical, relational bullying, or cyberbullying.

Recruitment for the sampling study was carried out through a general online assessment of bullying to determine whether participants experienced bullying and through a partnership between school teachers in Surabaya as a liaison between students in schools.

Probable participants were explained about the research, data collection procedures and consent forms by online using Google Forms. Data collection used pseudonyms to identify participants. Potential respondents who agreed were recorded and documented by the researcher. Participants were informed that their participation was voluntary, anonymous, and confidential; also, they could stop at any time. They were also told that the data submitted to researchers would not be disseminated and did not affect student learning outcomes.

Interviews were conducted using a general question guide regarding adolescent personal experiences on bullying at school. This interview also included questions about their opinions or perceptions about the prevention of bullying in schools through school health programs to find out what kind of school environment is ideal for preventing bullying. Researchers used social media to gather data, ranging from video calls or using short message, the variations depending on the willingness of each respondent. Interviews ranged from 45-110 minutes; the length of time during the interview depended on the participants' desire to share their experiences.

Qualitative data from all respondents were recorded and transcribed by the first researcher and continued with the analysis process by all authors. In detail, the first step was to extract the data and ensure its accuracy for analysis. The next stage entailed identifying from the statements and keywords submitted by the respondents related to the general topic of bullying and then identifying and grouping according to the theme. A collection of themes was combined into a more general global theme.

The data collection protocol has been approved by the ethics commission in the health sector at the Faculty of Nursing, Universitas Airlangga, certificate number No.2096-KEPK.

\section{RESULTS}

There were 18 participants of age range 13-15 years old. The number of male and female participants was 6 and 12 students, respectively $(\mathrm{N}=18,33 \%$ male and $67 \%$ female). Most of them have experienced verbal bullying, but not a few have experienced physical bullying as well as cyberbullying. Bullying occurred at school outside of lessons, both among classmates or levels, see Table 1.

Results from the thematic network analyses were grouped into three main themes identified from interviews with students: (1) Health education (2) Health services and (3) Health school environment, see Table 2. In order to better illustrate each theme, direct quotes for students were reported, respectively. 
Table 1. Characteristic of Participant $(n=18)$

\begin{tabular}{ccccc}
\hline Code & Age & Gender & Class & Type of Bullying \\
\hline P1 & 14 & Female & 8 & Verbal Bullying \\
P2 & 15 & Female & 9 & Verbal Bullying \\
P3 & 14 & Female & 8 & Cyberbullying; verbal bullying \\
P4 & 13 & Male & 8 & Verbal Bullying \\
P5 & 14 & Female & 9 & Verbal Bullying \\
P6 & 14 & Female & 8 & Cyber-bullying \\
P7 & 14 & Female & 8 & Cyber-bullying \\
P8 & 13 & Female & 8 & Verbal Bullying \\
P9 & 13 & Female & 8 & Verbal Bullying \\
P10 & 13 & Male & 8 & Verbal Bullying; cyberbullying \\
P11 & 15 & Female & 9 & Verbal Bullying \\
P12 & 13 & Female & 8 & Physical bullying \\
P13 & 14 & Male & 8 & Cyber-bullying \\
P14 & 13 & Male & 8 & Verbal Bullying \\
P15 & 14 & Female & 8 & Verbal Bullying \\
P16 & 14 & Female & 8 & Cyberbullying; Physical Bullying \\
P17 & 13 & Male & 8 & Physical Bullying \\
P18 & 14 & Male & 9 & \\
\hline
\end{tabular}

*P = Participants

Table 2. Theme Distribution of Study

\begin{tabular}{lll}
\hline \multicolumn{1}{c}{ Themes } & Sub-Theme & \multicolumn{1}{c}{ Quotes } \\
\hline $\begin{array}{l}\text { Health } \\
\text { education }\end{array}$ & Media & $\begin{array}{l}\text { Q1: "In my opinion, health education media is important, this interesting learning will be } \\
\text { easy to understand and remember" (P1) }\end{array}$ \\
& & Q2: "Schools are mostly monotonous, there are only posters, and I am not interested in \\
& Seeing information on posters. I prefer to look at electronic media" (P3) \\
& Q3: "It has been done, but not frequently and continuously. Usually through counseling by \\
Method & teachers at certain events" (P4)
\end{tabular}

Q4: "The counseling given was good, but my classmates also paid less attention, so they didn't know what bullying was and what the limits were" (P7)

Q5: "If using drama, it will definitely be more exciting and interesting, each student is able to analyze what happened to the perpetrators and victims of bullying. This will be more catchy and easier to remember" (P13)

School Q6: "I think the health program only has a youth red cross, helping the teacher when a Program student fainted during the Monday flag ceremony" (P11)

Q7: "In my opinion, the program is interesting, so it must be adjusted according to our age, there is an anti-bullying month program or other spiritual programs" (P2)

\begin{tabular}{lll}
\hline $\begin{array}{l}\text { Health } \\
\text { services }\end{array}$ & $\begin{array}{l}\text { Students } \\
\text { Service } \\
\text { providers }\end{array}$ & $\begin{array}{l}\text { Q8: "I feel embarrassed, so I am more free to tell my own friends, for example, we have a } \\
\text { problem" (P10) }\end{array}$ \\
& $\begin{array}{l}\text { Q9: "I had time to tell my teacher, but when I meet on other occasions I definitely feel } \\
\text { insecure, so telling stories with friends seems more comfortable" (P8) }\end{array}$ \\
& $\begin{array}{l}\text { Q10: "The most influential in giving advice and motivation is my teacher" (P10) } \\
\text { Tervice } \\
\text { providers }\end{array}$ & $\begin{array}{l}\text { Q11: "I feel safer, more comfortable, more relieved when I talk to my teacher, because the } \\
\text { information is protected" (P15) }\end{array}$
\end{tabular}

Q12: "Teachers do not favoritism, so we are comfortable telling stories" (P6)

Q13: "I think that, what my teacher conveyed must be appropriate, and the information must be correct" (P2)

Screening Q14: "In that school there is no mental health screening, usually physical health measures weight, is there any congenital disease, for example asthma, etc., but there is no bullying screening" (P2)

Q15: “Actually, we better know from the beginning whether we are classified as the bully or not" (P14)

Q16: "Maybe it could be during the student orientation period, that we checked one by one whether it was included in the bullying category, then we explained the information about bullying" (P17) 


\begin{tabular}{lll}
\hline \multicolumn{1}{c}{ Themes } & Sub-Theme & \multicolumn{1}{c}{ Quotes } \\
\hline $\begin{array}{l}\text { Healthy } \\
\text { school } \\
\text { environment }\end{array}$ & $\begin{array}{l}\text { Lack of } \\
\text { school } \\
\text { environment }\end{array}$ & $\begin{array}{l}\text { Q17: "Sometimes there are schools with empty hallways, usually it was being high risk of } \\
\text { becoming a place of bullying" (P18) }\end{array}$ \\
& & $\begin{array}{l}\text { Q18: "In schools there should be CCTV, to monitor student activities, it can be placed in the } \\
\text { classroom or in a strategic place" (P10) }\end{array}$
\end{tabular}
classroom or in a strategic place" (P10)

Health Q20: "Which is often contested is a class cleanliness competition, even though class promotion cleanliness is just like that. When it comes to bullying, there should be an anti-bullying competition ambassador contest" (P9)

Q21: “Other health promotions include competitions, poetry competitions or songs about bullying" (P3)

Q22: "Yes, it was very important. In my opinion, making slogans or slogans catchier and easier to remember" (P16)

School policy Q23: "Yes there must be, the rules in my school are mostly about discipline, for example punishment for students who are late, do not do homework, fight" (P4)

Q24: "If the rules for physical bullying such as fighting at school already exist, but if you make fun of it, it doesn't exist" (P13)

Q25: “If no one reports it, the teacher sometimes doesn't know, so you have to remind and report any bullying at school" (P8)

Q26: "In essence, the existing rules must be strengthened again, tightened again, because children in this era are very easy to violate" (P11)

\section{Theme 1: Health Education}

Health education is the most important thing in handling bullying cases, according to the problem, many people did not know about the boundaries that lead to bullying to students. The participants said that health education can increase their knowledge. This theme can be identified from the sub-themes of health promotion media, health promotion methods and school program. Health promotion media must be adjusted to the age target and would be more attractive if it was based on electronics (quotes 1-2). Health promotion method or health counseling with lectures seems less effective; at their age they prefer attractive education and all participants should be involve to participate in the promotion (quotes 3-5). Another interesting thing is the school program; school programs related to health must be more creative and make activities that involve all students so that they can train cohesiveness and togetherness between students (quotes 6-7).

\section{Theme 2: Health Services}

This health service theme shows more about the role of teachers and students in school when handling bullying cases. Both of them show that they are interrelated and have an influence in preventing adolescents bullying in school. By the guidance of counseling or discussion booths, some students stated that they were more comfortable telling stories with the teacher because they felt it was easy to find solutions and information was protected (quotes 1013 ) and some of them were more comfortable telling stories with their own friends because they could tell honestly without feeling embarrassed between students (quotes 8-9). Screening or assessment at the beginning is also an important value for students because it is able to detect early whether the individual is at low, medium or high risk of becoming a victim or perpetrator of bullying (quotes 14-16).

\section{Theme 3: Healthy School Environment}

A healthy school environment is also an indicator in improving the students' health status in schools. Based on the results of the interviews, there are three main topics that affect the handling of bullying cases in schools, including the unsuitable school environment, competition for health education activities and school policies. These three aspects are considered capable of supporting bullying prevention programs in schools. The school environment they want is a safe, comfortable and conducive one, supported by direct monitoring from the school and optimizing development facilities (quotes 17-19). To support activities at school, participants said that health promotion about bullying needs to be intensified with a competition method that involves all students to train together (quotes 20-22). The policies or regulations established by each school already have standards in the prevention of juvenile delinquency, but need to be improved and tightened (quotes 23-26). 


\section{DISCUSSION}

Research on bullying prevention carried out in schools has been extensively documented; however, a deeper understanding of the trajectories and experiences across students about a development plan of bullying prevention-based health promoting school remains underexplored. This study aimed to generate insights on the students' perceptions and the development of a health promoting school in preventing bullying in schools using multiinformants, in-depth, and a qualitative approach by students. Information based on the support desired by students in preventing cases of bullying in schools includes health education, health services and healthy school environment.

The results showed that media information, delivery information methods and school activities had a clear relationship to increase knowledge about bullying. Recent study shows that, media information can significantly increase knowledge, so they are able to report bullying incidents through the student empathy approach (Chaux, Velásquez, SchultzeKrumbholz, \& Scheithauer, 2016). This mediation of empathy is in line with the findings that empathy therapy is able to reduce bullying behavior in the 1112 year age group (Fatimatuzzahro \& Suseno, 2017).

The results showed that classmates and teachers have an important role in preventing bullying cases. One of the important aspects in the school environment was the teacher's role, where teachers who have a broader knowledge of the bullying phenomenon will be more effective in managing problems, and they have a more supportive attitude toward the victims (De Luca, Nocentini, \& Menesini, 2019; Lester, Waters, Pearce, Spears, \& Falconer, 2018). For instance, students indicated the support that should be given to victims of bullying and other students regardless of blood relations or closeness between schools. On the other hand, teachers have an important role to play in creating an effective learning environment; this can help students develop and control emotions and cognition in an adaptive way (Black \& Allen, 2018). Indirect effects of teacher emotional support on students' engagement and motivation indicated significant mediating effects of autonomy (Ruzek et al., 2016).

Screening specifically for high-risk groups can assist the intervention process. A recent study shows that screening of risk behaviors significantly affects detecting risky behavior and identifying the need for intervention (Kaess et al., 2014). In addition, screening helps prevent the development of adverse attitudes that are more severe and difficult to control (O'Connor et al., 2018). Another advantage of detection is that it guarantees that judgment is conveyed on the basis of the detection of preclinical status and clinical residual (Seltzer, Menoch, \& Chen, 2017).

Regarding the problem of implementing a health promoting school, students described the importance of creating a healthy and safe school environment; this can be realized through the application of regulations in schools. A handful of countries also have bullying prevention programs, and these can be integrated into health education standards, and / or teacher professional development (Department of Health and Human Services, 2018). In some cases, the term distinction is important because it will lead to different perceptions and meanings; the definition of bullying usually includes an imbalance of power as an element, while laws on harassment do not necessarily require such (Cornell \& Limber, 2015). Schools have a legal responsibility to maintain a safe environment that allows children and youth to continue their education and other services or opportunities available at the school, and minimize the incidence of bullying (National Academies of Sciences, Engineering, 2016).

\section{CONCLUSION}

This study seeks to identify students' needs for teacher social support and to include individual perspectives on bullying prevention in schools through a health school promoting approach. To our knowledge, this study is the only one that involves many students in researching bullying prevention from a student perspective. Media and method to deliver information about bullying is a necessary part of bullying prevention. Screening and type of social support, such as emotional support, rewarding and information, have an important role in preventing bullying in schools, from both teachers and students' perspectives. In addition, strengthening can be done by establishing a safe and comfortable school environment through the implementation of school regulations, so that it is hoped that the number of bullying incidents in schools can be reduced.

\section{REFERENCES}

Acosta, J., Chinman, M., Ebenera, P., Malone, P. S., Phillips, A., \& Wilks, A. (2019). Evaluation of a Whole-School Change Intervention: Findings from a Two-Year Cluster-Randomized Trial of the Restorative Practices Intervention. $J$ Youth Adolesc, 48(5), 876-890. https://doi.org/10.1007/s10964-019-01013-2

Ali, A., Mobarki, S., Mohamed, N., Morsi, A., \& Hamouda, G. (2020). Teachers 'Perception Regarding Bullying Behavior in Elementary Schools at Jizan City. 7(1), 742-751.

Barrington, K. (2018). How Does Bullying Affect a Student's Academic Performance? Retrieved from Public School Review website: https://www.publicschoolreview.com/blog/how -does-bullying-affect-a-students-academicperformance

Black, S., \& Allen, J. D. (2018). Part 7: Rewards, Motivation, and Performance. Reference Librarian, 59(4), 205-218. https://doi.org/10.1080/02763877.2018.14991 64

Blust, K. E. (2016). Middle School Teachers' 
Perceptions of Bullying and Their Practices in Reporting Bullying Incidents. ProQuest Dissertations and Theses, 254. Retrieved from http://search.proquest.com/docview/18005338 25?accountid=10673\%5Cnhttp://openurl.ac.uk/ athens:_edu?url_ver=Z39.88-

2004\&rft_val_fmt=info:ofi/fmt:kev:mtx:dissertati on\&genre=dissertations $+\% 26+$ theses \&sid=ProQ: ProQuest+Dissertations+\%26+Theses+Global\&at itle=\&title

Bowes, L., Aryani, F., Ohan, F., Haryanti, R. H., Arsianto, Y., Budiyawati, H., ... Ulum, D. F. (2019). The development and pilot testing of an adolescent bullying intervention in Indonesia - the ROOTS Indonesia program The development and pilot testing of an adolescent bullying intervention in. Global Health Action, 12(1). https://doi.org/10.1080/16549716.2019.16569 05

Chaux, E., Velásquez, A. M., Schultze-Krumbholz, A., \& Scheithauer, H. (2016). Effects of the cyberbullying prevention program media heroes (Medienhelden) on traditional bullying. Aggressive Behavior, 42(2), 157-165. https://doi.org/10.1002/ab.21637

Cornell, D., \& Limber, S. P. (2015). Law and policy on the concept of bullying at school. American Psychologist, $\quad 70(4), \quad 333-343$. https://doi.org/10.1037/a0038558

De Luca, L., Nocentini, A., \& Menesini, E. (2019). The teacher's role in preventing bullying. Frontiers in Psychology, https://doi.org/10.3389/fpsyg.2019.01830

Department of Health and Human Services. (2018). Laws, Policies \& Regulations. Retrieved from https://www.stopbullying.gov/resources/laws

Devlin, D. N., Santos, M. R., \& Gottfredson, D. C. (2018). An evaluation of police officers in schools as a bullying intervention. Evaluation and Program Planning, 71(March 2017), 12-21. https://doi.org/10.1016/j.evalprogplan.2018.07. 004

Fatimatuzzahro, A., \& Suseno, M. N. (2017). Efektivitas terapi empati untuk menurunkan perilaku. Jurnal Empati, 7(3), 362-378.

Fekkes, M. (2016). Effects of the Dutch Skills for Life program on the health behavior, bullying, and suicidal ideation of secondary school students. 116(1), 2-15. https://doi.org/10.1108/HE-052014-0068

Hayes, P. A. (2017). An Examination of Teachers' Perceptions of Bullying in an Urban Elementary School. Retrieved from http://www.bakeru.edu/images/pdf/SOE/EdD_T heses/HayesPatricia.pdf

Jan, M. S. A. (2015). Bullying in Elementary Schools : Its Causes and Effects on Students. 6(19), 43-57.

Kaess, M., Brunner, R., Parzer, P., Carli, V., Apter, A., Balazs, J. A., ... Wasserman, D. (2014). Riskbehaviour screening for identifying adolescents with mental health problems in Europe. European Child and Adolescent Psychiatry, 23(7), 611-620. https://doi.org/10.1007/s00787-013-0490-y

Kementerian Pendidikan dan Kebudayaan. (2012). PEDOMAN PELAKSANAAN UKS.

Khidhir, S. (2019). Bullying in Indonesia. Retrieved from The Asean Post website: https://theaseanpost.com/article/bullyingindonesia

Låftman, S. B., Östberg, V., \& Modin, B. (2017). School climate and exposure to bullying: a multilevel study. School Effectiveness and School Improvement, 28(1), 153-164. https://doi.org/10.1080/09243453.2016.12535 91

Lester, L., Waters, S., Pearce, N., Spears, B., \& Falconer, S. (2018). Pre-service teachers: Knowledge, attitudes and their perceived skills in addressing student bullying. Australian Journal of Teacher Education, 43(8), 30-45. https://doi.org/10.14221/ajte.2018v43n8.3

Meriläinen, M., Kõiv, K., \& Honkanen, A. (2019). Bullying effects on performance and engagement among academics. Employee Relations, 41(6), 1205-1223. https://doi.org/10.1108/ER-112017-0264

Murshid, N. S. (2017). Bullying victimization and mental health outcomes of adolescents in Myanmar, Pakistan, and Sri Lanka. Children and Youth Services Review, 76, 163-169. https://doi.org/10.1016/j.childyouth.2017.03.00 3

National Academies of Sciences, Engineering, and M. (2016). Preventing Bullying Through Science, Policy, and Practice. https://doi.org/https://doi.org/10.17226/23482

O'Connor, E. A., Perdue, L. A., Senger, C. A., Rushkin, M., Patnode, C. D., Bean, S. I., \& Jonas, D. E. (2018). Screening and Behavioral Counseling Interventions to Reduce Unhealthy Alcohol Use in Adolescents and Adults: Updated Evidence Report and Systematic Review for the US Preventive Services Task Force. JAMA - Journal of the American Medical Association, 320(18), 19101928. https://doi.org/10.1001/jama.2018.12086

Olweus, D., Limber, S. P., \& Breivik, K. (2019). Addressing Specific Forms of Bullying: A LargeScale Evaluation of the Olweus Bullying Prevention Program. International Journal of Bullying Prevention, 1(1), 70-84. https://doi.org/10.1007/s42380-019-00009-7

Pontes, N. M. H., Pontes, M. C. F., Ayres, C. G., \& Lewandowski, C. (2018). Trends in bullying victimization by gender among US high school students. (August 2017), 1-9. https://doi.org/10.1002/nur.21868

Puspita, R. (2019). The number of violence against children in East Java has decreased during 2019. Retrieved January 9, 2021, from https://republika.co.id/berita/daerah/jawatimur/q39k2h428/angka-kekerasan-terhadapanak-di-jatim-turun-selama-2019

Ruangnapakul, N., Salam, Y. D., \& Shawkat, A. R. 
(2019). A systematic analysis of cyber bullying in Southeast Asia countries. International Journal of Innovative Technology and Exploring Engineering, 8(8), 104-111.

Ruzek, E. A., Hafen, C. A., Allen, J. P., Gregory, A., Mikami, A. Y., \& Pianta, R. C. (2016). How teacher emotional support motivates students: The mediating roles of perceived peer relatedness, autonomy support, and competence. Learning and Instruction, 42(May), 95-103. https://doi.org/10.1016/j.learninstruc.2016.01.0 04

Seltzer, M., Menoch, M., \& Chen, C. (2017). Opportunistic Screening for Exposure to Bullying in the Pediatric Emergency Department. Global Pediatric Health, 4, $2333794 X 1771437$. https://doi.org/10.1177/2333794x17714377

Shayo, F. K., \& Lawala, P. S. (2019). Does bullying predict suicidal behaviors among in-school adolescents? A cross-sectional finding from
Tanzania as an example of a low-income country. BMC Psychiatry, 19(1), 1-6. https://doi.org/10.1186/s12888-019-2402-2

Sittichai, R., \& Smith, P. K. (2015). Bullying in SouthEast Asian Countries: A review. Aggression and Violent Behavior, 23, 22-35. https://doi.org/10.1016/j.avb.2015.06.002

Smith, P. K. (2016). Bullying: Definition, Types, Causes, Consequences and Intervention. Social and Personality Psychology Compass, 10(9), 519532. https://doi.org/10.1111/spc3.12266

Tong, A., Sainsbury, P., \& Craig, J. (2007). Consolidated criteria for reporting qualitative research (COREQ): A 32-item checklist for interviews and focus groups. International Journal for Quality in Health Care, 19(6), 349-357. https://doi.org/10.1093/intqhc/mzm042

UNICEF. (2018). Bullying. Retrieved from https://www.unicef.org/egypt/bullying 